\title{
Activity: A Basic Teaching Form of Morality and Rule of Law Lessons in Primary Schools
}

\author{
Mingzhi Li \\ The First Central Primary School of Linba Town, Dazhou, China
}

Email address:

419577644@qq.com

To cite this article:

Mingzhi Li. Activity: A Basic Teaching Form of Morality and Rule of Law Lessons in Primary Schools. International Journal of Elementary Education. Vol. 9, No. 2, 2020, pp. 46-49. doi: 10.11648/j.ijeedu.20200902.14

Received: June 14, 2020; Accepted: July 10, 2020; Published: July 22, 2020

\begin{abstract}
As a basic teaching form of morality and rule of law lessons in primary school, activity plays a significantly importance role in mobilizing the students' enthusiasm and subjective initiative. By participating in a variety of activities, students can improve their knowledge structure and enrich their life experience, thereby promoting the formation of students' correct concepts and good qualities. There are massive activities which can be designed by teachers to trigger students' creativity and enhance their practical ability. In this paper, methods, openness, integration of activities as well as how to conduct the activities are investigated. In general, the activities of morality and rule of law lessons in primary schools mainly include: observation activities, investigation activities, discussion activities, visit activities, production activities, planting activities, breeding (feeding) activities, exchange activities, participation in ceremonial activities, filial piety activities, environmental protection activities. These activities can be arranged before, during or after class by combination with other activities, such as class activities, school activities, festival activities and family activities. Based on different themes of teaching, it is suggested that teachers can conduct these activities by direct activities or communication activities. It is widely acknowledged that the activities of a class often exist in a comprehensive way. The development of activities can achieve the best teaching results by taking the teaching content and the actual situation of the class into consideration.
\end{abstract}

Keywords: Activities, Morality and Rule of Law, Students, Teaching Form

\section{Introduction}

In recent years, as an important part of primary school education in China, morality and rule of law lessons are prominent in many courses. Teachers should focus on the actual life and psychological needs of primary school students, and solve the relationship with themselves, with others, with the collective, with the country and society [1-2]. With a view to the healthy growth and all-round development of students, teachers should take on the educational mission given by the times [3-4].

A notable feature of morality and rule of law lessons is focusing on the connection between students' life experience and social practice. The aim of this course is mainly to provide students' experience, perception and automatic construction during the activities under the guidance of the teachers. By participating in a variety of activities, students can evidently improve their knowledge structure and enrich their life experience, thereby promoting the formation of students' correct concepts and good qualities [5-6].

Therefore, in classroom teaching, teachers are supposed to follow practical principles, take students as the foundation, and design classroom practical activity programs around the problems in students' lives, so as to help students profoundly understand and master the requirements and norms of social life [7]. Excellent practical activity design can not only help stimulate students' interest in learning and attract students to participate in active inquiry, but also promote the formation of their good behavior habits [8]. As a result, the four basic characteristics of morality and rule of law lessons consist of activity, daily life, comprehensiveness, and openness. The activity has also become the basic form of teaching and learning in moral and rule of law courses. In this paper, methods, openness, integration of activities as well as how to conduct the activities are systematically investigated. 


\section{Methods of Activities}

Considering that there are different contents and meanings, activities can be classified into several kinds. Generally, the activities of morality and rule of law lessons in primary schools mainly include: observation activities, investigation activities, discussion activities, visit activities, production activities, planting activities, breeding (feeding) activities, exchange activities, participation in ceremonial activities, filial piety activities, environmental protection activities. Through these methods, students interact with the environment and collaborate with their classmates to gain personal experience and feelings about themselves, others, nature and society, and hence triggering their creativity and enhancing practical ability effectively.

It should be noted that the left behind children (students) in rural areas caused by population flow has become a social problem that cannot be ignored [9-10]. Although the number of the left behind children in rural areas in China has gradually decreased in recent years, the number of left behind children in rural areas still exceeded 10 million in 2017, as displayed in Figure 1. The decrease of parents' company and neglect of education are the biggest reasons for most left behind children to become problem children. Many parents are going closer to their children with the economy slows and more and more cities tries to make more jobs in the inland economy [11-12]. That means they can see their children as often as every few weeks, rather than only once a year or less. And technology can put parents in touch with their offspring relatively inexpensively. From the perspective of these left behind children, however, active participation in different activities can efficiently reduce their loneliness and help them interact with peers while building correct outlook on life, value as well as the world.

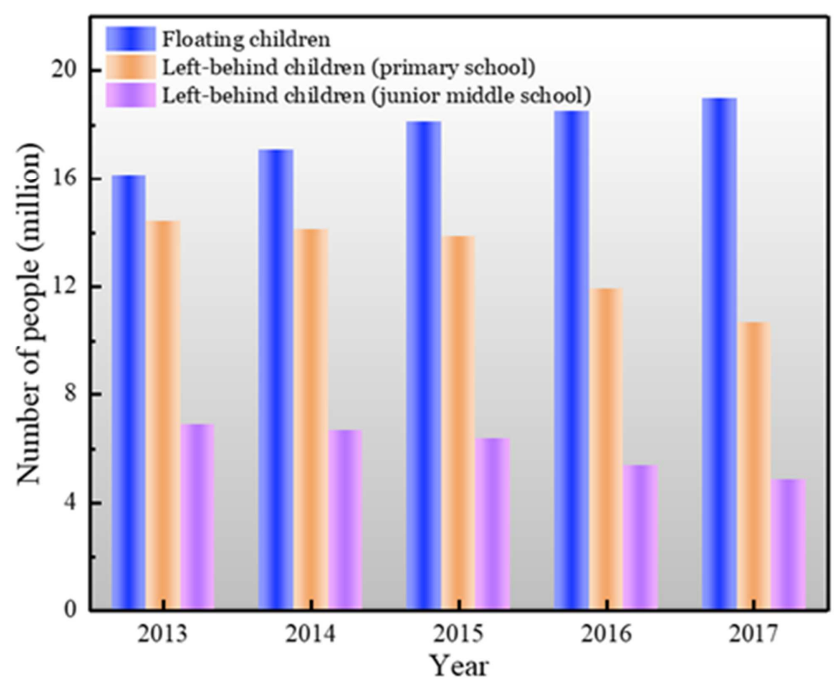

Figure 1. Changes in the number of children receiving compulsory education in China from 2013 to 2017.

\section{Openness of Activity Time}

According to the arrangement system of morality and rule of law lessons in primary schools and children's cognitive laws, activities can be arranged before the class. For example, based on the textbook "Morality and Rule of Law" approved by Chinese Ministry of Education in 2017, students from Grade Two are encouraged to plant a peanut with the guidance of their parents, and they can also plant sprouted potatoes and flowers purchased online. Through planting activities, they can learn to plant correctly under the guidance and communication of family members and classmates, learn to write planting notes, experience the process of plant growth, and then love the fruits of others' labor and cherish the life of plants. When teaching this lesson, the activity becomes communication activity between teachers and students. If there is no planting activity before the course, the curriculum objectives are not achieved in children's experience, perception, and active construction, making the teaching activities in this lesson impossible.

Activities can also be carried out during the class. For instance, teachers and students can participate in the activities of greeting cards and caring walls arranged in "New Year's Gifts" class (the 16th class of the textbook "Morality and Rule of law" approved by Chinese Ministry of Education in 2016). In this kind of production activities, students can learn to write blessings in accordance with their identity and raise hopes according to different objects.

Likewise, activities can be conducted after class. In the "Doing housework" class, the activities can be changed in time and place. There is another trick that teachers can arrange for the children to return to their own home to have an "exam". Students are inquired to take out their own clothes and review the method of folding clothes, which is instrumental in obtaining practical ability and rich life experience.

Flexible scheduling of activity time is conducive to opening the barrier between family, community and classroom. The non-enclosed class model helps students broaden their horizons and enrich their mind.

\section{Integration of Activities}

Based on different life situations/activities, moral and rule of law courses can be divided into different areas, as illustrated in Table 1. Studying in different fields can help students form a good outlook on life.

Table 1. Main scenarios in moral and rule of law courses.

\begin{tabular}{ll}
\hline Primary school & Junior middle school \\
\hline My healthy growth & Individual \\
My family life & Family \\
My school life & School \\
Our community life & Society \\
Our national life & Country \\
Our common life & World \\
\hline
\end{tabular}

It is a continuous development process for student to form their character and behavior habits and accumulate knowledge and experience in their lives [13]. As a result, strengthening the integration and continuity between 
educational activities is essential for improving the effectiveness of the curriculum. The activities of morality and rule of law lessons should be combined with other activities that students involved in, as shown in Figure 2.

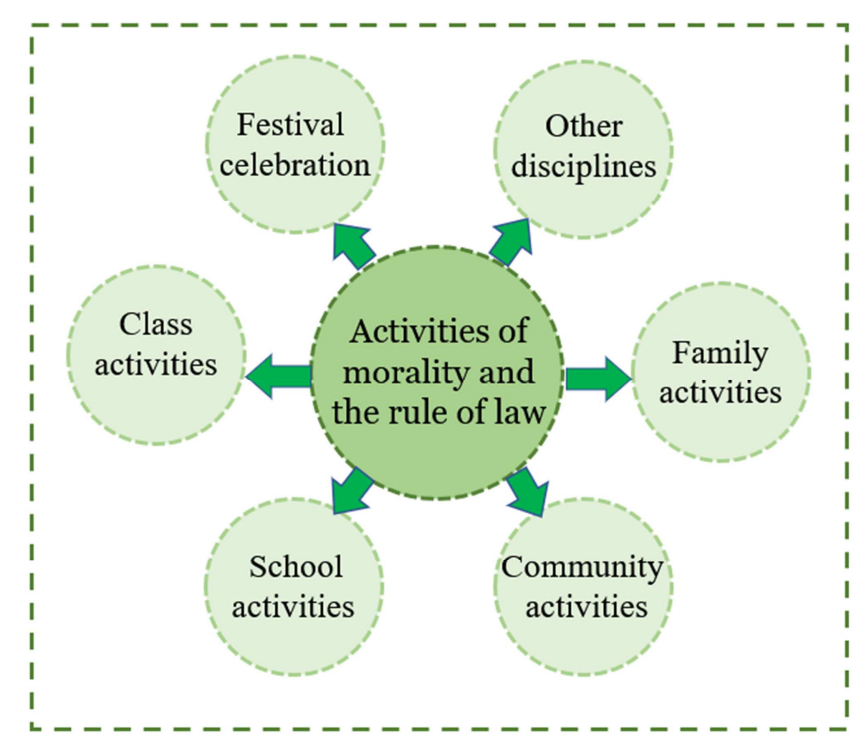

Figure 2. The activities of morality and rule of law lessons can be combined with other activities.

(1) Class activities. There is no doubt that it should be combined with class activities, such as class rules and dressing up the classroom. By combining with the class adviser, the teachers can guide the students to participate in these activities to maximize the effect of the teaching activities.

(2) School activities. It should be combined with school activities, such as caring for public property, not throwing things around, learning to line up and so on. In school activities, the effect of teaching activities on the habits of students can be checked effectively. Through the school activities, feedback on the effect of teaching activities can be obtained to further guide and teach the students. The courses can continuously influence children's real life by combining the requirements of teaching activities as well as school activities.

(3) Community activities. In general, there are some similarities between safety education activities, theme recreational activities and morality and rule of law. Teachers can take advantage of these similarities and combine them with community activities so that children can gain deepening experiences.

(4) Festival celebration. Teachers can use national day to educate and guide children to strengthen patriotic feelings and establish lofty aspirations. At present, many parents and teachers tend to pay more attention to intellectual education than moral education for students' growth and regard patriotic education for them as a matter of school, which is wrong. Class is the cell of society and the social window of life. The quality of patriotic education directly affects the healthy growth of children. Therefore, students have responsibilities and obligations to do a good job in patriotic education for their students. Also, students can understand the origin and customs of the Mid-Autumn festival and master and understand the poems and verses about the Mid-Autumn Festival.

(5) Other disciplines. The activities of making greeting cards, as mentioned in section 2, can be integrated with the art discipline. The greeting cards made by students can be more artistic, appreciative and collectible. Our life in Qingming can be also integrated with information technology course. Through the online activities of sacrificing heroes, the memorial ceremony for ancestors is organically combined with the love and reverence for heroes, which is beneficial for cultivating students' patriotic feelings and spread positive energy.

(6) Family activities. Students spend a long time in the family, have blood and family ties with their families while having family members to accompany and guide them in activities. Family education and school education can also be well combined. Children can go to school with the company of their families, so as to understand what is on the road, what needs attention, how children think and what their families require. Through the "stampede" activities with family members, communication activities in the classroom, and discussion activities among students, children will understand that there are various dangers on the way to school and establish a sense of safety.

\section{How to Conduct the Activities}

\subsection{Direct Activities}

According to the theme of teaching, teachers can directly arrange students' activities, so that students can experience in the activities. In activities, children's emotions, attitudes, cognitive abilities, moral habits and behavior habits, learning methods and characteristics are fully displayed and gradually formed. These activities include the making of greeting cards, the experience of the meaning of ringing tones, the arrangement of classrooms, the singing of the national anthem, the poetry recitation activities related to the Mid-Autumn Festival, etc. Such activities account for the vast majority in morality and rule of law lessons.

\subsection{Communication Activities}

Communication activities are arranged before class and the activity cycle is relatively long. Students gain a lot through speculation, imagination, observation, record and discovery. After activities, students can share their findings and experiences with others in class under the supervision of the teachers. This kind of activity comprises the planting and breeding activities as well as the way students go to school accompanied by their families. If the condition permits, students may take photos and make slides to make the class more attractive.

Activities are of importance in morality and rule of law lessons in primary schools, but they can't be just a simple form. Activity design by teachers must be based on the 
students' real life and attack their enthusiasm, making the classroom alive.

It is widely acknowledged that the activities of a class often exist in a comprehensive way [14-15]. The development of activities can achieve the best teaching results by taking the teaching content and the actual situation of the class into consideration.

\section{Conclusion}

In this study, methods, openness, integration of activities, as well as how to conduct the activities are systematically investigated. Based on the results, following conclusions are achieved:

(1) The activities of morality and rule of law lessons in primary schools mainly include observation activities, discussion activities, visit activities, production activities and so on.

(2) These interesting activities can be arranged before, during or after class by combination with other activities, such as class activities, school activities, festival activities and family activities.

(3) Based on different themes of teaching, it is suggested that teachers can conduct these activities by direct activities or communication activities. The development of activities can achieve the best teaching results by taking into account the teaching content and the actual situation of the class.

\section{Acknowledgements}

The author would like to thank Gan $\mathrm{Li}$, a PhD candidate, for his warm help and useful suggestions. The author would also like to thank Ms. Biying Chen for her support and concern for this paper.

\section{References}

[1] Sunyi Chen. Research on the Application of Traditional Cultural Resources in the Course of Morality and Rule of Law $[\mathrm{J}]$. The Theory and Practice of Innovation and Entrepreneurship, 2019.

[2] JinZhao Chen. On the Rule of Law in the Socialist Legal System in China [J]. Journal of Beijing Union University (Humanities and Social Sciences), 2016.
[3] H.-C. Stoeklé, Deleuze J F, Vogt G. Society, law, morality and bioethics: A systemic point of view [J]. Retour au numéro, 2019: 22-26.

[4] Shaonan Zhang. Chinese Pre-Service Teachers' Perceptions of Effects of Teacher Self-Disclosure [J]. New Horizons in Education, 2008, 56: 30-42.

[5] Rogers P J, Aston F. Teaching Method, Memory and Learning: an enquiry with primary school children [J]. Educational Studies, 1992, 18 (2): 129-149.

[6] Koca, Şehriban. Opinions of Prospective Primary School Teachers about Reflection of Micro Teaching Method on their Music Teaching Skills [J]. International Journal of Social Sciences \& Education, 2013.

[7] Jingzhong Y, Lu P. Differentiated childhoods: impacts of rural labor migration on left-behind children in China [J]. Journal of Peasant Studies, 2011, 38 (2): 355-377.

[8] Jia Z, Tian W. Loneliness of left-behind children: a cross-sectional survey in a sample of rural China [J]. Childcare Health \& Development, 2010, 36 (6): 812-817.

[9] Fan F, Su L, Gill M K, et al. Emotional and behavioral problems of Chinese left-behind children: a preliminary study [J]. Social Psychiatry \& Psychiatric Epidemiology, 2010, 45 (6): 655-664.

[10] Qiang Li, Gordon Liu, Wenbin Zang. The health of left-behind children in rural China [J]. China Economic Review, 2015: 367-376.

[11] Yu-Fen Yang, Nai-Cheng Kuo. New teaching strategies from student teachers' pedagogical conceptual change in CALL [J]. System, 2020, 90: 102218.

[12] Vatty K D. Teachers' beliefs about feedback practice as related to student self-regulation, self-efficacy, and language skills in teaching English as a foreign language [J]. Studies in Educational Evaluation, 2020, 64: 100828.

[13] Grossman P, Kazemi E, Kavanagh S S, et al. Learning to facilitate discussions: Collaborations in practice-based teacher education [J]. Teaching \& Teacher Education, 2019, 81: 97-99.

[14] Hotaman D. The teaching profession: knowledge of subject matter, teaching skills and personality traits [J]. Procedia Social \& Behavioral Sciences, 2010, 2 (2): 1416-1420.

[15] Huang X, Lee J, Yang X. What really counts? Investigating the effects of creative role identity and self-efficacy on teachers' attitudes towards the implementation of teaching for creativity $[\mathrm{J}]$. Teaching and Teacher Education, 2019, 84: 57-65. 